\title{
Towards an Emotional Geography of Eating Practices: an exploration of the food rituals of women of colour working on farms in the Western Cape
}

\author{
DEIDRÉ D. MATTHEE \\ Independent Scholar
}

\begin{abstract}
Eating and its associated activities are embodied, social practices that are meaningful and meaning-making. In order to explore the emotional geographies of eating practices, this article draws on a qualitative study of the everyday food rituals of female farm workers of colour in the Western Cape province of South Africa. Drawing on interview transcripts analysed using a social constructionist approach, three themes are elaborated, concerned with knowing, agency and community in relation to which the transformative potential of women's participation in food practices in the space of the kitchen is explored. In the ritual of preparing food, knowing is demonstrated as embodied activity with possibilities of corporeal transformation. As an embodied way of knowing, food-making also enhances women's sense of agency. Furthermore, eating rituals do not simply endorse a celebration of community, but call for a re-appreciation of women's positions and their power to shape relations and spaces of resistance.
\end{abstract}

\section{Introduction}

The investigation of embodied, social practices has become a challenging imperative in the social sciences. In this context, the practices and rituals associated with eating present an important and potentially illuminating area of study. This short article sketches out an emotional geography of eating practices embedded in the everyday lives of six female farm workers of colour placed in the Winelands area of the Western Cape province in South Africa. My argument places particular emphasis on the ever-present possibilities for transformation contained within traditional and often constraining gender roles. Drawing on Gill Valentine's (1999) analysis of the 'spatial dynamics of cooking and eating', I show how (re)negotiating food practices can enable constricting narratives of identity to be challenged, reshaped and replaced.

My account has its origins in a project designed to investigate psychological distress and resilience among women of colour ${ }^{1}$ in the Western Cape, exploring their everyday activities, thus including food rituals. The larger investigation involved the recruitment of 40 female farm workers ${ }^{2}$ in the Winelands area (socalled because viticulture is the predominant farming industry in the region). Six

Correspondence: Deidré D. Matthee. E-mail: deidrematthee@yahoo.co.uk 
participants, their ages ranging from 20 to 56 years, were selected for the part of the study reported in this article. Each participant was interviewed on a weekly basis for five or six weeks, by the same interviewer, drawn from a small research team of which I was a member. The interviews were semi-structured, open-ended sessions, each of which lasted for about two hours, covering a range of topics on the women's life-styles and experiences. All interviews were conducted in Afrikaans, the first language of the participants, and took place in a setting convenient for the participants. The material about women's eating rituals and food practices formed one of the interviews, which also addressed the topics of motherhood and sexuality. Because this topic was my particular area of interest, I designed this part of the interview schedule and I briefed the other interviewers involved about the nature and purpose of this component of the research.

This research was inspired by my own stories about eating rituals, which brought about an awareness that my relationship with food and eating was spiced with meaning. As a woman of colour who grew up in Paarl (known for its wine and the monument of the Afrikaans language), I related to the sometimes close-to-home quality of the participants' tellings (literally, in terms of location and language, but also in the way their stories would resonate with some of mine), while also being aware of how my position as middle-class researcher affiliated with an ivory-tinted intellectual institution distanced me from these narratives.

The interview transcripts were analysed using a grounded theory approach informed by social constructionism. This analysis generated evidence around three key themes concerned with knowing, agency and community, through which the discussion in this article is organised. As the ensuing discussion elaborates, rituals of preparing food involve embodied knowing, which enhances women's sense of their capacities as transformative agents. This sense of agency, performed within relational contexts, introduces the link between eating rituals and notions of community, thereby opening up spaces in which to reshape women's familial and societal positions. All this is played out in the arena of the kitchen and around the table.

\section{Knowing: getting (more) out of the kitchen}

Understanding eating rituals as meaningful and meaning-making prompts consideration of how women who prepare food come to know and experience themselves as knowers through their participation in these rituals. Acts of making food, performed in the spaces of kitchens, reveal a sense of owning and embodying knowledge attained through hands-on experience. This is powerfully illustrated in the example of baking bread, an activity carried out by all the participants, to which they refer primarily in terms of kneading the dough. For example, Carey ${ }^{3}$ recounted how she was trained in the act of 'kneading bread' under the supervision of her aunt:

The first time - my aunt taught me how to knead bread - she stood by me; and if I added water, she would tell me 'That's enough, now you must knead a bit more' and then I went on with it.

The physical presence of her aunt, and Carey's act of continuously handling the dough, form an image of tangibility-it is in the corporeal act of applying her hands to a lump of dough under the watchful instruction of her aunt that Carey's 
knowing is shaped. Lisa Heldke (1992, p. 218), in her discussion of the 'thoughtful practice' of making food, names knowing created through this activity as 'bodily knowing', and draws attention to the idea that this is more than a figure of speech, but is 'an acknowledgement of the fact that I know things literally with my body, that I, "as" my hands, know when the bread dough is sufficiently kneaded'. Carey also made mention of her mother being an 'old hand' at cooking, further conveying the impression of a mature wisdom of the hands:

Look, those are old hands, as folk would say. You can taste it: it's an old hand who made the food...

The notion that knowledge does not reside 'in the mind' but is enacted in the performance of preparing food is evident in Roos's response to a request for her favourite recipe:

I don't know recipes off the top of my head...sometimes I can't remember so well... but when I stand by the cupboard, and I look at it like this, then I remember again this must go in and that must go in, then I make something.

\section{Agency: moving beyond the kitchen}

As the quotations above suggest, participants' accounts of food-making demonstrate that knowing is grounded in the body: this knowing materialises in the way they carry their bodies temporally and spatially, in corporeal comportment and movement. However, a celebration of embodied knowing can risk neglecting the constraints women suffer in their association with (the burdens of) food preparation. As Lisa Heldke (1992, p. 211) argues, '[t]here is very little sympathy - either in Plato or in contemporary life-for the idea that foodmaking activities are valuable because of, not in spite of, the fact that they ground us in the concrete, embodied present'. Thus, women's knowledge embodies oppressive gendered discourses, such as the belief that a woman's place is limited to the kitchen, as suggested by Elize when she says:

If a man asks her 'make me something to eat'...I mean, then she must do it, because she's made to stand behind the pots. She is actually there to stand behind the pots. I take it, women are informed... Men-they don't care, they grab everywhere, maybe they'll wash their hands...They come back from labor outside and just grab bread...do what they want. But...a woman knows how. She is informed. Almost like a computer!

In this account, women are located 'behind' (the pots or the stove), while men can come and go as they please. But, although the kitchen may be an area to which women are confined and relegated, Elize also hints that it is a domain in which women can decide their movements and exercise control. To the question of what she enjoys about making food, Roos answers: 'To stand in front of the pots'. Positioning herself 'in front of' (as opposed to 'behind') the pots, suggests a sense of agency. She went on to explain 'look, then you can do anything'.

The spatial transformation displayed in Roos's shift from occupying the kitchen out of obligation to owning the kitchen as a space where there is room to move is integral to women's capacity for agency. That women's embodied knowledge as discerned in food-making does not necessarily commit their bodies to the kitchen 
was further fleshed out by Roos's assertion that although 'a woman must at least know her story in front of the stove ${ }^{4}$, she does not proscribe or prescribe foodpreparation, or decide the appropriate limits of activity, when it comes to instructing her daughter:

She must decide for herself... Because I didn't have my mom teach me. Because then I'd be in the garden, then I'd be in the house. I am everywhere...I am outside and inside. So I won't tell her where she should or shouldn't fit in.

Thus, revaluing food-making as a ritual that also involves the opportunity to produce and change within and beyond the space of the kitchen echoes Ian Burkitt's (1999, p. 77) contention that the acquisition and application of corporeal capacities hold possibilities for transformation; and especially his call to consider 'the way in which human activity transforms its spatial and temporal situations and thus reorients the contexts of activity'.

\section{Community: turning (to) the table(s)}

The site of the table invokes ideals of togetherness in the ritual of family meals. Understandings of community and sociality are intricately woven into the fabric of familial ties, and bound up with the common symbol of eating as communion. Participants highlighted Sunday lunches as a time and space set aside for being together as a family:

Roos: Sundays you have time...Saturday-evenings you start preparing your food. It must be something the family can look forward to...A little extra effort for Sundays...Everyone eats together...

Carey: Look during the week we don't worry much with fancy food, but Sundays... We make proper food on Sundays. We want to feel we eat on a Sunday. Then there's nice time to do it, nice time to prepare a nice dish for your family. Sundays we all eat together at home.

This 'tradition', as participants pointed out, has its roots in the designation of Sunday as a day of rest in the predominantly Christian heritage of these farm workers. That a substantial portion of time is dedicated to preparing and sharing a meal when opportunity allows reflects the significance attributed to this eating ritual. The Sunday meal is singled out as a time for togetherness. As such, it is constructed by expectations of delicious difference and needed nourishment as promised by the idea of a 'proper' meal: cooked food (preferably hot, connoting warmth), particularly prepared by the mother (symbolic of nurture), and served at the table (signifying togetherness) (Lupton, 1994).

The cord that holds this practice together is that of the family. The performance of this eating ritual takes place at the central setting of the table. And, if not enacted according to this socially prescribed order, the authenticity and significance of eating together as a family is somehow diminished, as Lorita explains:

We are not like a family who sits down to a meal at a table. I bought a table with two chairs, but no-one sits at that table. No-one uses him [the table]. Not even Sundays. The other day I told my daughter 'Why don't you just make some food. Just a piece of meat and a piece of 
bread';...Then I said 'Because what's the point of making lots of food if we don't sit together at the table.'

Lorita's statement hints at the erosion of the once sacred rule of breaking bread together at the table. Could it be that this ritual is merely a relic of the past? This possibility is suggested by the nostalgic tone of Roos's recollection of mealtimes during her childhood:

I remember when we'd eat...we would all sit together at the table. Each of us had a bowl, this kind of plastic bowl... And we ate together. We all ate together in those days.

In several geographical contexts it has been suggested that the 'family meal' functions as a fiction. For example, with reference to the UK, Anne Murcott (1997, p. 38) argues that there is very little empirical evidence of the waning of the family meal, merely nostalgia for a fictional image:

An idea of family meals, however real, remains just that, an idea. It is thus potentially redolent of ideology, social prescription and ideals. The idea portrayed is real enough, but that is not to say it is a faithful reproduction of some truth in the way that the photograph is (erroneously) supposed to be.

Murcott (1997) draws attention to the influence of socio-historical contexts and socio-political factors at play in the construction of the powerful, mythical concept of 'family-meals', with a family happily seated around a table, sharing a nourishing meal, and equally wholesome conversation. The symbol of the table, however shaky its legs may be, remains standing, precisely because it is 'just an idea'. And the table constitutes an important site at which discourses of gender and power are played out.

It is at the table where women are positioned as responsible for sustaining family life. Lorita's reflection that it is only the female members of her family who attempt to hold the ritual of eating at the table draws on the discourse that women are relationally bound, while men are mobile and independent:

I dish up and then we bless the table, but the husband is outside, he works in the garden... and the child [her son] comes when he wants to. So it's only me and my daughters...Us women...

The role of women as 'servers and providers' (Kerr \& Charles, 1986) is endorsed by these women as reflected by the following descriptions of mealtimes at the table:

Carey: ...Those who are women-like my sister and I-have to serve the others and so on.

Roos: I remember...my dad would call us for mealtimes, and my mom would dish out the food, while we were seated at the table.

Various 'humorous' mealtime anecdotes recounted by the participants not only exposed family harmony as myth but also elaborated gendered and racial lines of power and oppression. The powerful voice of the patriarch (father or white farmer) is heard in Roos's father's joke that people of colour can be kept quiet if their mouths are full: 
No, we'd chat. Sometimes we'd talk, sometimes we were quiet, and you'd hear my dad say: 'Yes, one can see $\mathrm{Gam}^{5}$ is eating, it's quiet.' [laughs] Even now when we eat: 'Yep, if Gam eats, then he's always quiet, he's busy.'

The maxim that children should be seen and not heard is expressed in the enforced silence described in Lorita's telling of a family meal scenario from her childhood:

And after our mom dished out the food, we'd all sit on that bench till we're finished eating. And we may not talk among each other. We have to sit dead quiet and eat. And if we talked, and my dad found out one of us chatted, then he'd hit all of us. One night he hit us, he used our own plates to hit us on our heads.

In these accounts, the picture of the 'togetherness' of the family at table is revealed as fabricated and fictional. As Anne Murcott (1997, p. 44) remarks '[g]ender, age and class all [...] start to break up an image of sharing at the dinner table by reflecting internal divisions of status and power in the domestic group'.

Declaring the ritual of sharing meals a false idol of communion undermines presumed meanings but does not replace them. The latter requires not just clearing of the table, but claiming it as a space where possibilities for participation can be re(ad)dressed. Lorita hinted at such possibilities.

I said 'We are never like a family. Seated at the table...' Then they say 'Yes but we're not Boers ${ }^{6}$...' Then I said 'It's not only Boers who can sit around a table! We can also do it.' Then I said 'Because I grew up in a house, we didn't have much furniture like other people-we didn't grow up like Boers, but my mother and father would sit at a table and-because we were many children, we had a long bench, and we'd sit on that bench-all of us together.'

While this could be viewed as another instance of conformity to the assumption of harmonious 'togetherness', Lorita's comments also convey other meanings as the bench on which she and her siblings had sat in the silence imposed by her father becomes a space of solidarity and resistance against dominant divisions of class and race ('but we are not Boers'). As Ian Burkitt (1999) argues, although relations of power and relations of communication are intertwined, they are not the same. The emotional geography of everyday eating rituals at least gesture towards transformative possibilities.

\section{Conclusion}

By exploring the performance of everyday eating rituals by women of colour working on farms this article has sought to contribute to the investigation of domains, such as kitchens, traditionally ignored by mainstream Western thought. I have shown how women's corporeal participation in cooking and eating practices enables a re-appropriation of space, and a concomitant reorientation to the transformative possibilities to be found in relational contexts. Central to this maneuver is a call to revisit the kitchen and the table as sites where possible transformation in relations of power and communication can be actualised. Starting with the activity of food-making that takes place in the kitchen, I have 
demonstrated how participants experience these practices as (per)forming embodied knowing, and as ways of claiming a sense of agency. This agency is clamed precisely where women are liable to entrapment. However, as Ian Burkitt $(1999,108)$ notes:

the body is not simply a product of relations of power, but also relations of communication and transformation, and as such is equipped with a variety of dispositions, capacities and potentialities that allow for agency and the constant possibility of social change.

This interpretation is also relevant to appeals to the table as the setting for socalled family meals. Uncovering the façade of togetherness leaves the table (as symbol of communion) without adequate legs on which to stand, and also undermines the recruitment of women into traditional gender roles. Alternative possibilities are suggested by participants' accounts, which signify the table as a space for reshaping relationality and resisting reified notions of power and structural division along lines of gender, class and race.

\section{Notes}

1. My use of the term 'of colour' (as opposed to 'coloured') is a matter of preference and defiance: as a woman of colour, I find the label 'coloured' stigmatising and fixing, marked by Apartheid South Africa's assumptions about identity — this is not to deny, but to state difference within a particular history.

2. The term 'farm worker' refers to people living and working on farms. Women qualified for this study if they lived on farms, and were employed as full-time, part-time, seasonal or domestic workers. Unemployed farm workers (i.e. those looking for work and ready to start working) were also included.

3. Participants are referred to by pseudonyms. Relevant excerpts from the transcribed interviews are translated from Afrikaans.

4. 'Knowing one's story' is an Afrikaans idiom for knowing (one's) ways about a particular matter.

5. Derogatory colloquial term for 'people of colour'.

6. A colloquial term with complex historical and political connotations used to refer to 'Afrikaners', 'whites' and/or 'farmers'.

\section{References}

Burkitt, Ian (1999) Bodies of Thought: embodiment, identity and modernity (London, Routledge).

Heldke, Lisa (1992) Foodmaking as a thoughtful practice, in: Deane Curtin \& Lisa Heldke (Eds) Cooking, Eating, Thinking: transformative philosophies of food, pp. 203-29 (Indianapolis, Indiana University Press).

Kerr, Marion \& Charles, Nickie (1986) Servers and providers: the distribution of food within the family, Sociological Review, 34, pp. 115-57.

Lupton, Deborah (1994) Food, memory and meaning: the symbolic and social nature of food events, Sociological Review, 42, pp. 664-86.

Murcott, Anne (1997) Family meals-a thing of the past?, in: P. Caplan (Ed.) Food, Health and Identity, pp. 32-49 (London, Routledge).

Valentine, Gill (1999) Eating in: home, consumption and identity, Sociological Review, 47, pp. 492-524. 
Copyright of Gender Place \& Culture: A Journal of Feminist Geography is the property of Carfax Publishing Company and its content may not be copied or emailed to multiple sites or posted to a listserv without the copyright holder's express written permission. However, users may print, download, or email articles for individual use. 